\title{
Use of home food digesters to reduce household waste
}

\section{K. Harder and R. Woodard}

European and UK legislation has led local authorities to implement waste prevention programmes and assess the options available for diverting waste from final disposal to landfill. Food waste is part of the waste stream where significant diversions can be made, with an estimated 6.7 Mt of such waste thrown out by UK households each year. One option available for managing food waste is the green cone (GC) food waste digester. The unit is installed at household level and is designed to accept all food waste including meat, fish and processed food. The unit heats up through solar gain and the waste in the GC is converted into water, carbon dioxide and a small amount of residue. This paper describes a project that directly investigated changes in waste by householders after they started using a GC food digester. A statistically significant reduction in waste was found, at a $\mathbf{9 9 \%}$ confidence level, in households using a GC food digester. An average reduction of $2 \cdot 1 \mathrm{~kg}$ of waste per household per week (from II.2 to $9 \cdot 1 \mathrm{~kg}$ ) was seen in a sample of 68 new GC users compared with a sample of 1446 control, non-users.

\section{INTRODUCTION}

Local authorities throughout the UK are working towards meeting statutory recycling targets. The recycling rate has increased significantly over recent years, from only $7 \cdot 5 \%$ of the waste stream being recycled in $1995^{1}$ to $27 \%$ in $2005 / 06 .^{2}$

While it is important to increase levels of recycling, it is always considered preferable to follow the order of priority given in the waste hierarchy, that is, reduce, reuse, then recycle. ${ }^{2}$ By generating less waste in the first place, fewer resources have to be spent on collecting, processing and disposing of waste. The importance of waste prevention is now being reflected in the Revised Waste Framework Directive wherein a target for member states to stabilise waste production by 2012 to levels produced in 2008 has been proposed. Moreover, the Thematic Strategy on the Prevention and Recycling of Waste requires member states to produce waste prevention plans. ${ }^{3}$

The Waste Strategy for England $2007^{2}$ recognises the need to focus efforts on waste prevention. The strategy sets out a series of targets for reducing the amount of waste sent for final disposal (i.e. waste generated that is not reused, recycled or composted) from over $22 \cdot 2 \mathrm{Mt}$ in 2000 to $12 \cdot 2 \mathrm{Mt}$ by 2020 -this is the equivalent of a reduction in annual household waste generation from $450 \mathrm{~kg}$ per capita in 2000 to $225 \mathrm{~kg}$ by 2020 .
Local authorities throughout the UK are using a range of waste prevention initiatives to reduce quantities of waste delivered for final disposal. Examples include the promotion of reusable nappies, home composting, smart shopping, opting out of receiving junk or unwanted mail and donating items for reuse. Further information on current waste prevention initiatives and options is available in the literature. ${ }^{4-6}$

\section{I.I. Food waste}

A further approach is to minimise the food waste components of household waste (or catering waste) entering the collection stream through the provision of waste digesters. Food waste typically comprises $17-22 \%$ by weight of an average weekly waste bin, ${ }^{7,8}$ and includes vegetables, fruit, cooked and processed foods, meat and fish.

Until 2003, local authorities in the UK were permitted to collect garden waste (organic matter including grass cuttings, prunings, fallen fruit, etc.) and food waste from households and then compost the material using open-air windrow systems. However, in 2001 an outbreak of foot and mouth disease led to the slaughter of some four million sheep, cattle and pigs. ${ }^{9}$ The suspected cause of the outbreak was the feeding of unprocessed food waste to animals. As a consequence, under the Animal ByProducts Order 1999 (amended in 2003), all food waste (catering waste), including source-separated material that could contain or have been in contact with meat or other products of animal origin, must now be disposed of in such a way that prevents its exposure to livestock and wild birds. ${ }^{10}$ This had implications for local authorities-unless they had an enclosed composting facility, they could no longer continue to collect and compost food waste.

Based on the latest available data from the Composting Association, in 2004/05 only 7\% of local authorities collected food waste along with garden waste from kerbsides; a further 3.5\% offered a dedicated collection of food waste. At present, only $13 \%$ of sites accept food waste and it is estimated that $4 \mathrm{Mt}$ was sent to landfill during $2004 / 05 ;^{11}$ recent research by the Waste and Resources Action Programme (Wrap) ${ }^{12}$ suggests this figure is far higher at 6.7 Mt. Diversion of this food waste from final disposal would result in significant economic savings from saved waste collection and processing costs along with associated environmental savings from reductions in transportation and greenhouse gas emissions from the degradation of food waste. Wrap 


\begin{tabular}{|ll|}
\hline Desirable GC materials & Materials not suitable \\
\hline Fish & Metal \\
Red meat and poultry & Wood \\
All bones & Plastic \\
Bread & Glass \\
Fruit, including peelings & Paper \\
Vegetables, including peelings & Straw \\
Dairy produce & Grass cuttings \\
Cooked food scraps & Hedge clippings \\
Crushed egg shells & Bulk oil \\
Tea bags & Disinfectant and bleaches \\
Animal excrement & Special treatment items \\
& \\
\hline Table I. Materials suitable for use in green cone waste digesters
\end{tabular}

estimates that $18 \mathrm{Mt}$ of carbon dioxide emissions are generated from the disposal of food waste. ${ }^{13}$

A variety of systems have been developed to help residents manage their waste at home. The green cone (GC) waste digester was developed to manage food wastes and other biodegradable wastes such as animal excrement (see Table 1). There is some confusion that the GC is actually a home composting system, but unlike a composter, the role of the GC is to act as a digestion unit, that is, to provide a place for waste to degrade in an accelerated fashion rather than producing a compost material. Other differences between a GC and a home compost unit are summarised in Table 2.

\section{I.2. The green cone}

The GC is a four-part plastic injection-moulded system comprising a digestion basket that is installed below ground and which forms the base for an above-ground double-walled solar chamber with an access lid (Figure 1). The design of the GC utilises solar heating in the double-walled chamber to facilitate and accelerate the aerobic decomposition process within the digestion basket. For the system to work effectively it should be installed to obtain maximum sunlight. Access to the GC is through a $20 \mathrm{~cm}$ diameter hole in the top of the unit, which is sealed with a hinged lid. An accelerator powder that contains bacteria can be added to assist the decomposition process.

Food waste that is placed into the GC is converted into water, carbon dioxide and a small amount of residue. In a welloperating system, the residue will occupy the bottom $25 \mathrm{~cm}$ of the digestion basket after decomposition of about $1 \mathrm{t}$ of food waste; the resulting water constituent escapes to the surrounding

\begin{tabular}{|lcc|}
\hline & $\begin{array}{c}\text { Home } \\
\text { composter }\end{array}$ & $\begin{array}{c}\text { Green } \\
\text { cone }\end{array}$ \\
\hline $\begin{array}{l}\text { Takes all food waste including meat, bones } \\
\text { and dairy products ('non-compostable }\end{array}$ & $\boldsymbol{x}$ & $\checkmark$ \\
kitchen waste') & & \\
Takes garden waste & $\checkmark$ & $\boldsymbol{x}$ \\
Requires good drainage & $\boldsymbol{x}$ & $\checkmark$ \\
Requires turning/mixing occasionally & $\checkmark$ & $\boldsymbol{x}$ \\
Installation requires digging a hole & $\boldsymbol{x}$ & $\checkmark$ \\
\hline Table 2. Key differences between green cone and home compost \\
unit
\end{tabular}

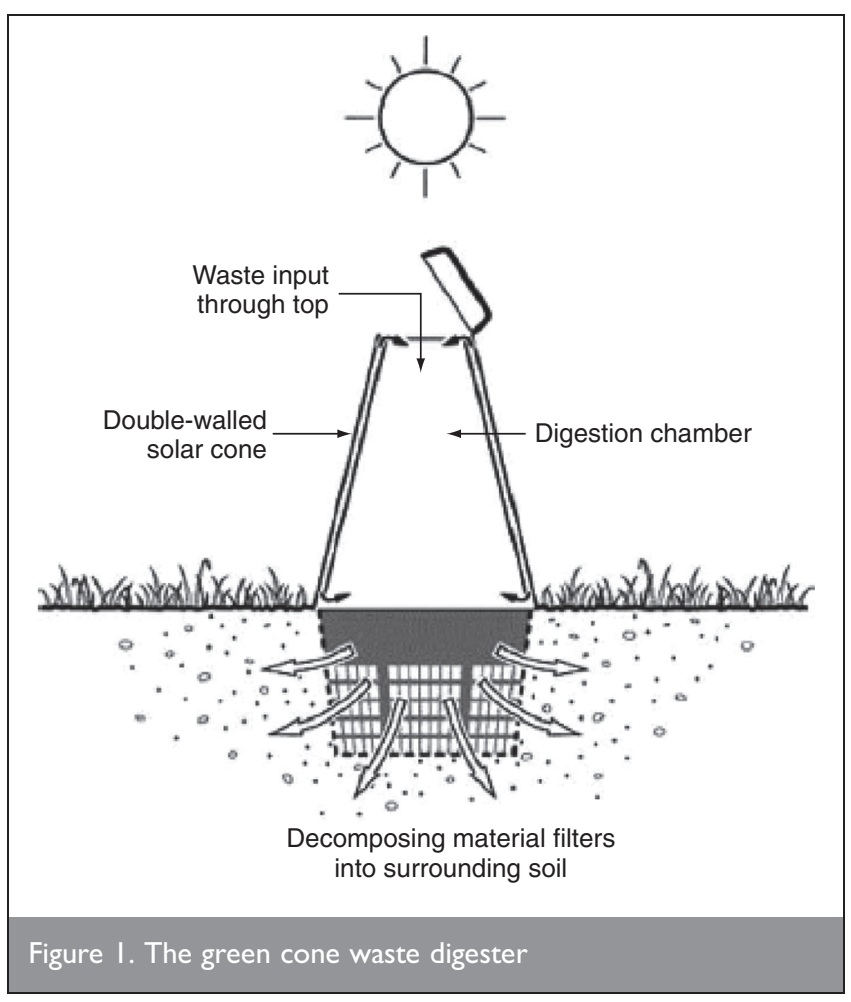

soil. After about five years (the duration varies depending on the feedstock and use of the unit) this small quantity of residue must be removed and dug into garden sub-soil.

The GC is being promoted extensively throughout the UK as well as parts of North America. For example, in Aberdeenshire, Aberdeen City and Moray, 3702 GC units were sold in 2002$2005 .{ }^{14}$ In Seattle, USA, 3600 units were distributed in a single day and 8000 households have purchased a GC over a period of 12 years. ${ }^{15}$ West Sussex County Council conducted a trial of GCs in 2002 and launched a county-wide promotion in 2004 with the aim of having 50\% of households with gardens using food waste digesters by $2015 .{ }^{16}$ Despite the increasing profile of the GC unit, relatively few research studies into their performance (or those of home food digesters generally) have been undertaken. Those studies that are available are not able to provide results that have been tested for statistical significance.

Bench et al. ${ }^{17}$ undertook a study in which households were provided with weighing equipment to monitor how much waste was being diverted into their GC. Sixty per cent of respondents stated that they had seen a reduction of $25-50 \%$ in the quantity of waste that they placed out for collection, and quantitative results showed that, on average, $2 \cdot 7 \mathrm{~kg}$ per week was diverted. Other research has shown conflicting results, with rates of diversion varying from $2 \cdot 2$ to $6.5 \mathrm{~kg}$ per household per week (see Table $3^{17-22}$ ). However, many of the studies involved only small numbers of households, and residents were aware that their behaviour was being observed.

Local authorities are required to justify their spending. It is thus necessary to determine, with more certainty, the amount of waste that could be diverted through GCs so that their use could be considered against the cost of public subsidy. This paper reports on a systematic study of 1957 households who were offered GCs and whose residual waste was individually weighed for four weeks before and four weeks after GC installation. 


\begin{tabular}{|lllcr|}
\hline Reference & $\begin{array}{c}\text { Year of } \\
\text { study }\end{array}$ & Location & $\begin{array}{c}\text { Number of } \\
\text { households }\end{array}$ & $\begin{array}{c}\text { Waste diverted to } \\
\text { green cone: kg/week } \\
\text { per household }\end{array}$ \\
\hline Todd $^{18}$ & 2001 & West Oxford & 32 & $2 \cdot 4$ \\
Jones $^{19}$ & 2002 & Moray & 63 & $2 \cdot 9$ \\
TWWC $^{20}$ & 2003 & Telford & 5 & $6 \cdot 5$ \\
Bench et al. $^{17}$ & 2005 & West Sussex & 48 & $2 \cdot 7$ \\
Gysin $^{21}$ & 2005 & Dorset & 95 & $3 \cdot 9$ \\
RBC $^{22}$ & 2005 & Rugby & 50 & $2 \cdot 2$ \\
& & & & \\
\hline
\end{tabular}

\section{METHODOLOGY}

In summer 2005, the University of Brighton in partnership with West Sussex County Council set out to determine whether the use of GC food digesters by householders in West Sussex could be correlated with a significant reduction in residual household waste set out for disposal. Data were collected using two methods.

(a) Waste placed out by householders for collection was weighed for four consecutive weeks before and four consecutive weeks after use of a GC (at least a month was allowed between the two periods for users to 'settle in'). It was hypothesised that those changing to GC use would have a reduced residual waste set out for collection.

(b) The composition of residual (black bag) waste of a sample of householders was analysed in detail both before and after the onset of GC use. These data were used to test the hypothesis that there would be reductions in specific waste materials that could be processed in GCs for those households that were using them compared with those that were not.

As the effects looked for were small, it was known from the outset that incorrect data from only two or three households could mask true effects. It was necessary to be certain whether every household used to test the hypotheses was using the GC or not. To this end, a programme of face-to-face questionnaires was carried out with householders. All householders in the sample were approached; not all were available (even after three visits) or willing to answer. Households whose use of the GC was unknown were discounted from the data set. However, the initial sample size was sized to take account of these and other 'wastages'.

\section{I. Overview}

The trial was conducted in an area where GCs had not previously been promoted. The sample consisted of approximately 500 households from the first half of a given daily collection round over four different collection days (i.e. 2000 in total). Rounds in four different villages or towns were chosen, and measurements started on 14 June 2005 for four weeks (phase 1). The second set of four-week measurements (phase 2) started on 6 September 2005. In both phases, in the fifth week, residual waste was taken from approximately 200 households for detailed analysis.

Normal waste collection was suspended each morning as university researchers went along the route weighing waste from every house using portable electronic scales. After 3-4h, council collection crews came in to collect the waste. The first half of the round was specifically chosen to ensure that all households would have their waste set out; those on the second half of the round might not have put their waste out until much households requesting GCs.

In the fifth week of phase 1, 175 households had their black bags removed and waste was analysed by material type; 275 households were similarly analysed in the fifth week of the post-GC period (phase 2). Of the 275 households in phase 2 , 51 were later found to have installed and used their GCs; 108 were definitely not using GCs and these were used as controls. The study only used data from those households definitely known to have have/have not installed and used their GCs.

\subsection{Kerbside weighing}

Surveyors used portable electronic industrial scales with an accuracy of $1 \mathrm{~g}$ to weigh waste at the kerbside of targeted households before collection. The waste was weighed in the containers used by each household since it was not feasible (noise disturbance, time constraints, etc.) to remove the waste from the container prior to weighing. At some point (e.g. later in the day after they had been emptied) the weights of the empty containers were recorded and noted for future reference and calculations. In cases where several houses used the same waste container (e.g. council-issued wheeled bins), the same weight was used for all relevant households. Any extra waste set out, for example, beside the containers but in plastic bags, was recorded separately in each case.

\subsection{Waste compositional analysis}

For compositional analysis, bags were removed from the kerbside of each targeted household and placed in a large sack labelled with a reference number. These were then removed to a sorting site where surveyors weighed them, separated the contents into the categories listed in Table 4 (based on Defra guidance $^{23}$ ) and noted the weight of each category for each reference number. The data were then analysed.

\section{RESULTS}

\section{I. Changes in average weight of waste}

Residual waste weights for each household for each week were averaged over phase 1 and again over phase two. For each household (1446 did not use the GC; 68 were known to have started using the GC), the difference between average phase 1 and phase 2 weights was calculated.

For data of this type, simple averages are not suitable, and more sophisticated statistical techniques are needed. For example, on average, GC users' residual waste decreased by $2 \cdot 1 \mathrm{~kg}$ in phase 2, while that of the control group (i.e. non-GC users) increased by $0 \cdot 2 \mathrm{~kg}$. However, in both cases the uncertainty in the 


\begin{tabular}{|c|c|}
\hline Primary material category & Example \\
\hline Cardboard & Card packaging, board packaging, liquid cartons, other card \\
\hline Compostable kitchen & Home-compostable kitchen waste, e.g. vegetable scraps, tea leaves \\
\hline Dense plastic & Clear and coloured plastic bottles, food packaging, other dense plastic \\
\hline Electrical equipment & Old household goods, e.g. kitchen appliances, radios, electronic toys \\
\hline Ferrous metal & Beverage cans, food cans, other cans, other ferrous \\
\hline Fines & Material less than $10 \mathrm{~mm}$, including soils \\
\hline Garden waste & - \\
\hline Glass & Glass bottles and jars \\
\hline Hazardous & Household and car batteries, chemicals, identifiable clinical, other potentially hazardous \\
\hline Miscellaneous combustibles & Treated wood, untreated wood, furniture, carpet and underlay \\
\hline Miscellaneous non-combustibles & Construction and demolition, masonry, ceramics \\
\hline Non-compostable kitchen & Non-home-compostable kitchen waste, e.g. meat, fish, bones, cooked foods, dairy products \\
\hline Non-ferrous metal & Beverage cans, foil \\
\hline Paper & Newspaper and magazines, other recyclable paper, paper packaging \\
\hline Plastic film & Packaging plastic film, plastic bags \\
\hline Textiles & Clothes, shoes, linen \\
\hline Disposable nappies & - \\
\hline
\end{tabular}

Table 4. Categories of waste used in this study

measurements was around $4 \mathrm{~kg}$. A more appropriate statistical test was thus used-in this case, a two-tailed $t$-test for two samples known to have different variances. This gave the result that the two samples were different at a high confidence level of 99\% (Table 5).

\subsection{Changes in waste composition}

Changes in composition of the residual waste before and after use of a GC was determined through detailed composition analysis of 153 and 159 households in phase 1 and phase 2 respectively. The analysis allowed comparison of the amounts of different materials in the residual waste of GC users and nonusers. The average quantity of waste set out for collection in phase 1 was $9 \mathrm{~kg}$ per household per week (Table 6). In phase 2, the average weight of residual waste placed out by those

\begin{tabular}{|c|c|c|c|}
\hline & $\begin{array}{l}\text { Households } \\
\text { using GC } \\
\text { in phase } 2\end{array}$ & $\begin{array}{c}\text { Control } \\
\text { (households } \\
\text { without } \\
\text { a GC) }\end{array}$ & $\begin{array}{l}\text { Valid } \\
t \text {-test? }\end{array}$ \\
\hline Number of households & 68 & 1446 & \\
\hline $\begin{array}{l}\text { Difference in residual } \\
\text { waste phase } 2-\text { phase } \\
\text { I: kg/week }\end{array}$ & $-2 \cdot 1$ & +0.2 & $\begin{array}{c}\text { Yes, } 99 \% \\
\text { confidence } \\
\text { level }\end{array}$ \\
\hline Standard deviation & $4 \cdot 3$ & 3.9 & \\
\hline
\end{tabular}

households that had installed a GC was $7.9 \mathrm{~kg}$ per week; in the same period the control group (i.e. households that had not installed a GC) set out $9 \cdot 2 \mathrm{~kg}$ waste per week.

The only category of residual material that can be placed in a GC but not in a composter is non-compostable food material such as meat and cooked food. This category thus represents exactly those materials that should be reduced in the waste stream of GC users who also have composters. On average, the households studied generated $1.5 \mathrm{~kg}$ per week of non-

compostable food waste in phase 1 ; this was reduced to $0.5 \mathrm{~kg}$ per week for GC users in phase 2. A two-tailed $t$-test showed this result to be highly statistically significant at the 99\% confidence level. For comparison, the control households generated $1 \cdot 1 \mathrm{~kg}$ of such waste per week in phase 2 .

Regarding all materials desirable for a GC, $3 \mathrm{~kg}$ per household per week was generated in phase 1 . In phase 2 , this reduced to $1 \cdot 7 \mathrm{~kg}$ per week for households using a GC; the control group remained consistent at $3 \cdot 1 \mathrm{~kg}$.

\section{CONCLUSIONS}

In trials conducted in Sussex, UK, the use of green cone food digesters was studied to determine if a statistically significant reduction of residual waste set out by households could be achieved. The study showed that households using GCs achieved a reduction in their set-out waste when compared with a control group, to a 99\% confidence level. On average, residual waste set out for collection was reduced by $2 \cdot 1 \mathrm{~kg}$ per week per household.
Number of households

Average residual waste: $\mathrm{kg} /$ household $/$ week

Non-compostable kitchen: $\mathrm{kg} /$ household/week

Standard deviation

Compostable kitchen: kg/household/week

Total GC-desirable material: kg/household/week

153
9
1.5
2.2
1.4
3.0

108

$9 \cdot 2$

$1 \cdot 1$

1.6

$2 \cdot 1$

$3 \cdot 1$ 
From a detailed composition analysis of the waste, households using a GC were found to set out less 'non-compostable food materials' than those not using a GC, to a 99\% confidence level. The average difference was found to be $0.6 \mathrm{~kg}$ per week.

No statistically significant reduction was found for the categories of compostable food waste or garden waste. Although food digesters can, in principle, take some waste from these categories, in this study they did not appear to be affected. It is considered that most households using food digesters already use composting units for these categories.

The results suggest that the GC food waste digester is an effective option to reduce the amount of food waste being sent for disposal. Previous studies were unable to reach this conclusion as the level of waste reduction cannot be shown to be significant without very large sample sizes; this study is the first to report such statistical significance.

The result is key to those working to divert household waste from the general waste stream, with waste reduction being placed higher on the waste hierarchy than recycling or city composting. For the first time, this research provides a clear indication that food digesters work to reduce residual household waste, along with a measure of that reduction. Local authorities can use this information to determine the relative benefits of promoting food digesters against other waste diversion techniques. However, it must be noted that the success of the method will depend on the attitude of the public, the availability of gardens and appropriate weather conditions.

\section{ACKNOWLEDGEMENTS}

This work was funded by the Department for the Environment, Food and Rural Affairs (Defra) through West Sussex County Council and by the University of Brighton through the Waste \& Energy Research Group (WERG).

\section{REFERENCES}

1. Department For Environment, Food and RuRal Affairs. Municipal Waste Survey 2001/02. HMSO, London, 2003.

2. Department for Environment, Food and RuRal Affairs. Waste Strategy for England 2007. The Stationery Office, London, 2007.

3. European Parliament. Environment Committee Takes First Steps to Sort Waste Directive. See http:// www.europarl.europa.eu/news/expert/infopress_page/064334-331-11-48-911-20061127IPR00318-27-11-20062006-false/default_en.htm for further details. Accessed 23/01/2007.

4. National Waste \& Resource Forum. Household Waste Prevention Toolkit. NWRF, London, 2004.

5. ENviros. International Waste Prevention and Reduction Practice: Final Report. Enviros, 2004.
6. Local Government Association. 10 Easy Ways to Prevent Waste. LGA, London, 2004.

7. Parfitt J. Analysis of Household Waste Composition and Factors Driving Waste Increases. Waste and Resources Action Programme, Banbury, 2002.

8. Poll J. Pilot Study on Municipal Waste Composition in Wales. AEA Technology, Didcot, 2002.

9. Department for EnVIronment, Food And RuRal Affairs. Foot and Mouth Disease 2001: Lessons to be Learned Inquiry Report. The Stationery Office, London, 2002.

10. Statutory Instrument No. 1482 The Animal By-Products Regulations. The Stationery Office, London, 2003.

11. Composting Association. The State of Composting in the UK Et Biological Treatment in the UK 2004/05. Composting Association, Northants, 2006.

12. Waste \& Resources Action Programme. The Food We Waste. WRAP, Banbury, 2008.

13. Waste \& Resources Action Programme. The food we waste. Presentation 8 May, London, 2008. See http:// http:// www.wrap.org.uk/downloads/

The_Food_We_Waste_Ray_Georgeson.ae43df87.pdf for further details. Accessed 15/06/2008.

14. Scottish EnVironment Protection Agency. Aberdeenshire, City of Aberdeen and Moray Area Waste Plan Annual Progress Report 2003-2004. SEPA, Stirling, 2004.

15. SHERMAn R. Backyard composting developments. Biocycle, 2005, 46, No. 1, 45.

16. West Sussex County Council. Draft Joint Materials Resource Management Strategy for West Sussex (2005-2035). West Sussex County Council, Chichester, 2005.

17. Bench M. L., Woodard R., Harder M. K. and Stantzos N. Waste minimisation: home digestion trials of biodegradable waste. Resources, Conservation and Recycling, 2005, 45, No. 1, 84-94.

18. Todd M. Green Cone Trial in West Oxfordshire A Report on the Findings. Oxford Brookes University, Oxford, 2001.

19. Jones M. The Waste Away Scheme. Phase II: A Quantitative Survey of the Effectiveness of The Moray Council's Waste Minimisation Scheme to Reduce Organic Kitchen Food Waste Going to Landfill. Roslyn Associates, 2002.

20. Telford and Wrekin Borough Council. The Telford \& Wrekin Wormery, Green Cone and Compost Bin Trial. TWBC, Telford, 2003.

21. GYsin R. Household Treatment of Food Waste in Dorset: Results of 52-week Trial of the Green Cone Food Waste Digester. Dorset County Council, Dorchester, 2005.

22. Rugby Borough Council. The Efficacy of the Green Cone Food Waste Digester as a Tool for Household Waste Minimisation. RBC, Rugby, 2005.

23. Department For EnVironment, Food and RuRal Affairs. Waste Composition Analysis Guidance for Local Authorities. The Stationery Office, London, 2004.

\section{What do you think?}

To comment on this paper, please email up to 500 words to the editor at journals@ice.org.uk

Proceedings journals rely entirely on contributions sent in by civil engineers and related professionals, academics and students. Papers should be 2000-5000 words long, with adequate illustrations and references. Please visit www.thomastelford.com/journals for author guidelines and further details. 